\title{
HUBUNGAN TINGKAT KONSUMSI ENERGI DAN PROTEIN DENGAN STATUS GIZI ANAK BALITA DI WILAYAH KERJA PUSKESMAS TALISE KECAMATAN MANTIKULORE KOTA PALU
}

\author{
${ }^{1}$ Windy Wiena Putri, ${ }^{2}$ Jamaluddin Sakung, ${ }^{3}$ Rochfika Suleiman \\ ${ }^{1)}$ Department Nutrition, Faculty of Public Health Muhammadiyah UniversityPalu \\ 2) Tadulako University \\ ${ }^{3}$ Department Occupational Health and Safety, Faculty of Public Health \\ Muhammadiyah UniversityPalu
}

\begin{abstract}
Nutritional problems still being main problems in countries such as Indonesia developing. Nutrition status is the one of indicators. Nutrition status of someone affected by variety of factors. The purpose to know what a correlation between the consumption level of energy and protein with nutrition status of kids under five years old in the work Public Health Centre Talise Mantikulore Palu. The method used is analytic survey that use crross sectional, with 73 respondent as sample, the analytic used in this research are univariat and bivariat analyzes by chi-square test.The results of statistical chi square test showed that is meaningful relation between the adequacy of energy and nutrition status of under five children by the $P$ Value 0,001and there is no meaningful relation between the adequacy of protein and nutrition status ofunder five children by the $P$ Value=0,222. Expected to health workers in Public Health CentreTalise to increase the health services for public especially nutrition program. To hold information about the importance of the consumption level of energy or protein. That decline of under five childrenexperienced lack of energy and protein so that it can be create degrees public health maximum.
\end{abstract}

\section{Keyword $\quad$ : Consumption Level of Energy, Protein, Nutritional Status}

\section{PENDAHULUAN}

UU Republik Indonesia Nomor 35 Tahun 2014 pasal 1 ayat 2 tentang perlindungan anak menjelaskan, bahwa perlindungan anak adalah segala kegiatan untuk menjamin dan melindungi anak dan hak-haknya agar dapat hidup, tumbuh, berkembang, dan berpartisipasi secara optimal sesuai dengan harkat dan martabat kemanusiaan, serta mendapat perlindungan dari kekerasan dan diskriminasi. Salah satu bentuk perlindungan pada anak adalah upaya perlindungan dari bahaya laten kehilangan generasi yang diakibatkan oleh gizi buruk mau pun gizi kurang. ${ }^{6}$
UU Republik Indonesia Nomor 36 Tahun 2009 tentang Kesehatan, di mana pemerintah, pemerintah daerah, dan masyarakat bersama-sama menjamin tersedianya bahan makanan yang mempunyai nilai gizi yang tinggi secara merata dan terjangkau (pasal 141 ayat 3). Bahkan, pemerintah harus bertanggung jawab atas pemenuhan kecukupan gizi pada keluarga miskin dan dalam kondisi darurat (pasal 142 ayat 30).

Status gizi merupakan salah satu faktor yang menentukan kualitas tumbuh kembang seseorang yang pada akhirnya berpengaruh terhadap kualitas Sumber Daya Manusia (SDM). Status gizi 
masyarakat sering digambarkan dengan masalah gizi pada kelompok anak balita. Kegiatan pemantauan anak balita gizi kurang merupakan kegiatan penting untuk kewaspadaan gizi sehingga dapat diketahui dengan cepat kasus yang terjadi di masyarakat. ${ }^{8}$

Setiap tahun lebih dari sepertiga kematian anak di dunia berkaitan dengan masalah gizi. Tercatat satu dari tiga belas anak di dunia meninggal setiap tahun akibat buruknya kualitas nutrisi. Sebuahrisetjuga menunjukkan pada tahun 2014 dari 50 juta anak setidaknya 16 juta anak mengalamigizi kurang maupun gizi buruk. ${ }^{5}$

Masalah gizi umumnya disebabkan oleh angka kecukupan energi dan angka kecukupan protein, kurangnya pengetahuan masyarakat tentang gizi, menu seimbang, dan adanya daerah miskin gizi. Berdasarkan laporan organisasi kesehatan dunia (WHO/Word Health Organization) menunjukkan bahwa kesehatan masyarakat Indonesia adalah peringkat terendah di ASEAN yaitu peringkat ke-142 dari 170 Negara. ${ }^{3}$

Anak balita (1-5tahun) merupakan kelompok umur yang paling sering menderita akibat kekurangan gizi (KEP) atau termasuk salah satu kelompok masyarakat yang rentan gizi. Kurang Energi Protein (KEP) adalah salah satu masalah gizi utama disamping masalah gizi lainnya.Menurut Riset Kesehatan Dasar Indonesia, terdapat $19,6 \%$ balita kekurangan gizi yang terdiri dari 5,7\% balita dengan gizi buruk dan 13,9\% berstatus gizi kurang. Sebesar 4,5\% balita dengan gizi lebih. ${ }^{11}$

Berdasarkan penelitian terdahulu Ferawati membuktikan bahwa adanya hubungan antara asupan energi protein dengan kejadian gizi kurang pada anak balita. $^{3}$

Data hasil pemantauan status gizi dari Puskesmas se-Kota Palu pada tahun 2014, prevalensi anak balita yang menunjukkan pola pertumbuhan yang terganggu Bawah Garis Merah (BGM)adalah 1,99\% yaitu sebanyak 629 anak balita (laki-laki 275 anak balita, perempuan 356 anak balita). Kejadian tertinggi berada pada wilayah kerja Puskesmas Kamonji yaitu sebanyak 180 anak balita, dan kejadian terendah berada pada wilayah kerja Puskesmas Singgani yaitu sebanyak 7 anak balita. ${ }^{9}$

Data hasil pemantauan status gizi di Puskesmas Talise pada tahun 2014, dari 1.443 jumlah anak balita yang berkunjung masih ditemukan banyaknya anak balita yang menunjukkan pola pertumbuhan terganggu Bawah Garis Merah (BGM) sebanyak 115 anak balita yang tersebar pada tiga wilayah kerja Puskesmas Talise, yaitu kelurahan Talise terdapat 65 anak balita, Kelurahan Tondo terdapat 30 anak balita, dan Kelurahan Layana terdapat 20 anak balita. ${ }^{4}$

\section{METODE}

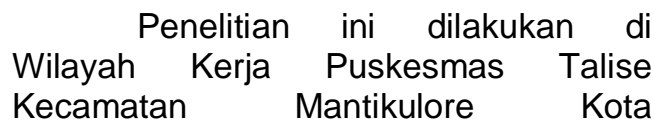
Palu.Populasi kunci dalam penelitian ini adalah seluruh ibu yang memiliki anak balita dan berkunjung diPuskesmas Talise pada saat penelitian. Sampel dan unit analisis dalam penelitian ini adalah seluruh anak balita pada saat penelitian berlangsung di Puskesmas Talise berjumlah 73 orang. Penelitian ini merupakan penelitian survey analitik dengan pendekatan Cross Sectional Study. Penelitian dilakukan dengan cara wawancara dan observasi langsung di lapangan menggunakan alat bantu food recall, kemudian data dianalisis dengan analisis Univariat dan Bivariat dengan menggunakan uji Chi-square.

\section{HASIL DAN PEMBAHASAN \\ Hasil \\ Analisis Bivariat}

a. Ada hubungan antara tingkat konsumsi energi dengan status gizi anak balita 
Tabel 1

Hubungan Tingkat Konsumsi Energi Dengan Status Gizi Anak Balita Di Wilayah Kerja Puskesmas Talise Kecamatan Mantikolore

\section{Kota Palu}

\begin{tabular}{|c|c|c|c|c|c|c|c|}
\hline \multirow{3}{*}{$\begin{array}{c}\text { Tingkat } \\
\text { Konsumsi }\end{array}$} & \multicolumn{4}{|c|}{ Status Gizi } & \multirow{2}{*}{\multicolumn{2}{|c|}{ Jumlah }} & \multirow{3}{*}{ p Value } \\
\hline & \multicolumn{2}{|c|}{$\begin{array}{c}\text { Tidak } \\
\text { Normal }\end{array}$} & \multicolumn{2}{|c|}{ Normal } & & & \\
\hline & (f) & $(\%)$ & (f) & (\%) & (f) & (\%) & \\
\hline $\begin{array}{l}\text { Tidak } \\
\text { tercukupi }\end{array}$ & 9 & 69,2 & 4 & 30,8 & 13 & 100 & \\
\hline Tercukupi & 11 & 18,3 & 49 & 81,7 & 60 & 100 & 0,001 \\
\hline Total & 20 & 27,4 & 53 & 72,6 & 73 & 100 & \\
\hline
\end{tabular}

Sumber: Data Primer, 2016

b. Tidak ada hubungan antara tingkat konsumsi protein dengan status gizi anak balita

Tabel 2

Hubungan Tingkat Konsumsi Protein Dengan Status Gizi Anak Balita Di Wilayah Kerja Puskesmas Talise Kecamatan Mantikolore Kota Palu

\begin{tabular}{|c|c|c|c|c|c|c|c|}
\hline \multirow{3}{*}{$\begin{array}{l}\text { Tingkat } \\
\text { Konsumsi }\end{array}$} & \multicolumn{4}{|c|}{ Status Gizi } & \multirow{2}{*}{\multicolumn{2}{|c|}{ Jumlah }} & \multirow{3}{*}{ p Value } \\
\hline & \multicolumn{2}{|c|}{$\begin{array}{c}\text { Tidak } \\
\text { Normal }\end{array}$} & \multicolumn{2}{|c|}{ Normal } & & & \\
\hline & (f) & $(\%)$ & (f) & $(\%)$ & (f) & $(\%)$ & \\
\hline Tidak tercukupi & 15 & 40,5 & 22 & 59,5 & 37 & 100 & \\
\hline Tercukupi & 5 & 13,9 & 31 & 86,1 & 36 & 100 & 0,222 \\
\hline Total & 20 & 27,4 & 53 & 72,6 & 73 & 100 & \\
\hline
\end{tabular}

Sumber: Data Primer, 2016

PEMBAHASAN

a. Hubungan tingkat konsumsi

energi

Berdasarkan hasil uji "chi square" nilai $p=0,001<0,05$, berarti secara statistik Ho ditolak, maka dapat disimpulkan ada hubungan antara tingkat konsumsi energi dengan status gizi anak balita.

Menurut asumsi peneliti, ratarata ibu responden telah memiliki pengetahuan dasar tentang pentingnya energi untuk menunjang pertumbuhan dan melakukan aktifitas fisik. Hal ini terlihat pada hasil penelitian dimana responden yang status gizinya normal dan asupan energinya tercukupi lebih banyak proporsinya dibandingkan dengan responden yang status gizinya tidak normal dan asupan energinya tidak tercukupi. Namun nafsu makan anak balita yang tidak menentu juga menjadi salah satu permasalahan, hal ini dapat dilihat dari hasil penelitian dimana masih banyaknya responden yang status gizinya normal tetapi 
asupan energinya tidak tercukupi dan responden yang status gizinya tidak normal tetapi asupan energinya tercukupi.

Hasil penelitian ini menunjukkan bahwa sejalan dengan hasil penelitian yang telah dilakukan oleh Ferawati, yang menyatakan bahwa hasil uji statistik ditemukan adanya hubungan yang bermakna antara angka kecukupan energi dengan status gizi anak balita. ${ }^{3}$

Hasil penelitian ini didukung oleh teori bahwa status gizi anak balita sangat dipengaruhi oleh angka kecukupan energi yang harus dikonsumsi setiap harinya. Karena manusia membutuhkan energi untuk mempertahankan hidup,menunjang pertumbuhan dan melakukan aktivitas fisik. ${ }^{10}$

Apabila konsumsi energi melalui makanan kurang dari energi yang dikeluarkan, maka akan terjadi kekurangan energi. Akibatnya berat badan akan kurang dari berat badan seharusnya(ideal).

Nafsu makan yang berubahubah dipengaruhi oleh beberapa hal seperti keadaan sehat dan tidak sehatnya kondisi fisik anak balita, interaksi dengan lingkungan, dan aktifitas anak balita. ${ }^{1}$

Adapun hasil penelitian ini tidak sejalan dengan penelitian Wahyuni, dengan menggunakan uji chi-square diperoleh nilai $P=0,08 \quad(P<0,05)$ yang artinya tidak ada hubungan yang bermakna antara angka kecukupan energi dengan status gizi anak balita di Desa Tinigi Kecamatan Galang Kabupaten Tolitoli. Dalam penelitiannya disebutkan bahwa dalam peningkatan angka kecukupan energi yang baik bukan hanya pengetahuan mengenai energi yang dibutuhkan tetapi juga perlu adanya dorongan atau motivasi baik dari diri sendiri maupun dari luar. ${ }^{13}$

\section{b. Hubungan tingkat konsumsi protein}

Berdasarkan hasil uji "chi square" nilai $p=0,222 \geq 0,05$, berarti secara statistik Ho diterima, maka dapat disimpulkan tidak ada hubungan antara tingkat konsumsi protein dengan status gizi.

Asumsi peneliti, rata-rata ibu responden akan merasa senang ketika melihat anak balitanya memiliki nafsu makan yang baik, dan tentu saja dengan senang hati ibu responden akan memberikan anak balitanya makanan, tetapi tanpa memperhitungkan terlebih dahulu apa saja kandungan gizi yang dibutuhkan bagi perkembangan dan pertumbuhan anak balitanya. Hal ini terjadi karna masih rendahnya pengetahuan ibu responden tentang keaneka ragaman makanan dan kandungan gizi apa saja yang dibutuhkan oleh anak balitanya terutama tentang angka kecukupan protein. Hasil penelitian menunjukkan walaupun pada kenyataannya anak balita yang status gizinya normal dan asupan proteinnya tercukupi lebih banyak, tetapi ternyata masih banyak pula anak balita yang status gizinya normal tetapi asupan proteinnya tidak tercukupi. Namun nafsu makan anak balita juga menjadi salah satu permasalahan, hal ini dapat dilihat dari hasil penelitian dimana masih adanya responden yang status gizinya normal tetapi asupan proteinnya tidak tercukupi dan responden yang status gizinya tidak normal tetapi asuapan proteinnya tercukupi.

Hasil penelitian ini sejalan dengan penelitian Wahyuni,yang menyatakan bahwa hasil uji statistik ditemukan adanya hubungan yang bermakna antara angka kecukupan energi dengan status gizi anak balita. ${ }^{12}$ Hasil penelitian ini didukung oleh teori bahwa diperlukan pengetahuan dan pemahaman ibu mengenai protein yang merupakan zat gizi yang sangat penting bagi tubuh karena selain sebagai sumber energi, protein juga berfungsi sebagai zat 
pembangun tubuh dan zat pengatur di dalam tubuh. Pola makanan yang kurang beragam memiliki arti bahwa balita tersebut mengkonsumsi hidangan dengan komposisi yang tidak memenuhi gizi seimbang. ${ }^{2}$

Protein sangat diperlukan oleh tubuh untuk kelangsungan pertumbuhan dan pemeliharaan jaringan, pembentukan senyawa tubuh yang esensial, regulasi keseimbangan air, mempertahankan netralitas tubuh, pembentukan anti body, dan transportasi zat gizi. ${ }^{1}$

Nafsu makan yang berubahubah dipengaruhi oleh beberapa hal seperti keadaan sehat dan tidak sehatnya kondisi fisik anak balita, interaksi dengan lingkungan, dan aktifitas anak balita. ${ }^{1}$

Adapun hasil penelitian ini tidak sejalan dengan penelitian Ferawati, dengan menggunakan uji chi-square diperoleh nilai $P=0,023(P>0,05)$ yang artinya ada hubungan yang bermakna antara angka kecukupan energi dengan status gizi anak balita Di Wilayah Kerja Puskesmas Sei Aur Kabupaten Pasaman Barat. Dalam penelitiannya disebutkan bahwa dalam peningkatan angka kecukupan protein yang baik bukan hanya asupan makanan, pengetahuan keanekaragaman makanan dan pengetahuan mengenai protein saja yang dibutuhkan tetapi juga ada faktor-faktor lain yang perlu dipertimbangkan seperti pekerjaan orang tua, pendidikan orang tua, penyakit penyerta dan lain-lain. ${ }^{3}$

\section{KESIMPULAN}

Berdasarkan hasil penilitian dan pembahasan maka peneliti dapat menarik kesimpulan sebagai berikut:

1. Ada hubungan antara tingkat konsumsi energi dengan status gizi pada anak balita di wilayah kerja Puskesmas Talise Kecamatan Mantikolore Kota Palu, dengan nilai $P$ Value $=0,001$
2. Tidak ada hubungan antara tingkat konsumsi protein dengan status gizi pada anak balita di wilayah kerja Puskesmas Talise Kecamatan Mantikolore Kota Palu, dengan nilai $P$ Value $=0,222$

\section{REKOMENDASI}

Diharapkan kepada petugas kesehatan di Puskesmas Talise agar dapat meningkatkan upaya pelayanan kesehatan kepada masyarakat khususnya program Gizi, untuk mengadakan penyuluhan-penyuluhan tentang pentingnya angka kecukupan energi ataupun protein agar menurunnya anak balita yang mengalami kekurangan energi dan protein sehingga dapat tercipta derajat kesehatan masyarakat yang setinggi-tingginya.

\section{DAFTAR PUSTAKA}

Devi, Nirmala. 2010. Nutrition and Food Gizi

Untuk Keluarga, PT. Kompas Media Nusantara, Jakarta.

Febry, Ayu Bulan, Zulfito Marendra. 2010.

Buku Pintar Menu Balita, PT. Wahyu Media, Jakarta Selatan.

Ferawati. 2012.Faktor Resiko Kejadian

Kurang Energi Protein (KEP) Pada

Balita di Wilayah Kerja Puskesmas

Sei Aur Kabupaten Pasaman Barat, Sumatra Barat.

Massi, Rahmat. 2014.Profil UPTDPuskesmas Talise Palu 2014, Puskesmas Talise, Palu.

Muchtadi, Deddy. 2010.Teknik Evaluasi

Nilai Gizi Protein, Alfabeta, Bogor.

Muliyawan. 2016.Paradigma Baru Hukum

Undang-Undang Perlindungan

Anak, Pengadilan Negri Palopo, Palopo.

Reppi, Bryan. 2015.Hubungan Antara Energi

Dengan Status Gizi Siswi SMA 4 Manado, (Tidak Diterbitkan), Skripsi, Fakultas Kesehatan 
Masyarakat Universitas Sam

Ratulangi Manado, Manado.

Ridwan, Muhammad. 2012.Gambaran Pola

Makan dan Status Gizi Anak BalitaMasihul Kecamatan Dolok Kabupaten Serdang Begadai, (Tidak Diterbitkan), Skripsi, Fakultas Kesehatan Masyarakat Universitas Sumatra Utara, Medan

Sukmawati, Emma. 2013.Profil Kesehatan

Kota Palu Tahun 2013, Dinas Kesehatan Kota Palu, Palu.

Supariasa, I Dewa Nyoman, Bakri. B, Fajar. I, 2013, Penilaian Status Gizi, EGC, Jakarta.
Supriyantoro. 2013.Profil Kesehatan Indonesia Tahun 2013, Jakarta.

Wahyuni, Sri. 2014.Hubungan Angka Kecukupan Energi dan Protein Dengan Kasus Gizi Kurang di Desa Tinigi Kecamatan Galang Kabupaten Tolitoli, (Tidak Diterbitkan), Skripsi, Fakultas Kesehatan Masyarakat Universitas Muhammadiyah Palu, Palu.

Widodo, Yekti, Salimar, Rustan. E. 2013.Penatalaksanaaan Anak Balita Gizi Buruk dan Gizi Kurang di Pos Pergizi atau Pos Gizi, Dinas Kesehatan Provinsi Sulawesi Tengah, Palu. 